\title{
Effects of subchronic methionine stimulation on oxidative status and morphological changes in the rat ileum
}

\author{
Dušan Todorović ${ }^{1, \star}$, Marija Stojanovićc ${ }^{1, \star}$, Ljiljana Šćepanović ${ }^{1}$, Dušan Mitrović ${ }^{1}$, Vuk \\ Šćepanović ${ }^{2}$, Radomir Šćepanović ${ }^{3}$, Teja Šćepanović ${ }^{4}$, Milica Labudović-Borović ${ }^{5}$, Vesna \\ Dragutinović 6 , Nevena Borozan ${ }^{7}$ and Dragan Djuric ${ }^{1}$ \\ ${ }^{1}$ Institute of Medical Physiology "Richard Burian", Faculty of Medicine, University of Belgrade, Belgrade, Serbia \\ ${ }^{2}$ Institute for Neurosurgery, Clinical Center of Serbia, University of Belgrade, Belgrade, Serbia \\ ${ }^{3}$ Belgrade University of Defense, Military Medical Academy, Belgrade, Serbia \\ ${ }^{4}$ Institute of Neonatology, Belgrade, Serbia \\ ${ }^{5}$ Institute of Histology and Embryology "Aleksandar Đ. Kostić", Faculty of Medicine, University of Belgrade, Belgrade, \\ Serbia \\ ${ }^{6}$ Institute of Medical Chemistry, Faculty of Medicine, University of Belgrade, Serbia \\ ${ }^{7}$ Faculty of Medicine, University of Belgrade, Belgrade, Serbia
}

\begin{abstract}
This study was conducted to explore the effects of sulfur containing amino acids on redox status and morphological parameters in the rat ileum tissue. Male Wistar albino rats were randomly divided into the following groups: K group (saline, $1 \mathrm{ml} /$ day, i.p.), M group (methionine, $0.8 \mathrm{mmol} /$ $\mathrm{kg} /$ day, i.p.), C group (methionine $(0.8 \mathrm{mmol} / \mathrm{kg} /$ day $)+\mathrm{L}$-cysteine $(7 \mathrm{mg} / \mathrm{kg} /$ day $)$, i.p.) and $\mathrm{N}$ group (methionine (0.8 mmol/kg/day) + N-acetyl-L-cysteine $(50 \mathrm{mg} / \mathrm{kg} /$ day $)$, i.p.). Activities of antioxidant enzymes in the ileum were analyzed to profile oxidative status. Morphometric analysis included measurement of villus height $(\mu \mathrm{m})$, tunica mucosa thickness $(\mu \mathrm{m})$, tunica muscularis thickness $(\mu \mathrm{m})$, the total thickness of the ileal wall $(\mu \mathrm{m})$ and the number of cells in the lamina propria $(p e r$ $0.1 \mathrm{~mm}^{2}$ of tissue). Results showed that methionine treatment reduced the activity of antioxidant enzymes (SOD, GPx, CAT) and the GSH content compared to the control group $(p>0.05)$. The application of methionine reduced the following parameters statistically significant compared to the control group: length of the ileal villi $(p<0.01)$, tunica mucosa thickness $(p<0.01)$, and ileal wall thickness $(p<0.01)$. We concluded that methionine induced the changes in the gut redox status, which implied oxidative stress occurrence. L-cysteine and N-acetyl-L-cysteine both exhibited antioxidant properties.
\end{abstract}

Key words: Rat - Ileum - Methionine - Oxidative status

\section{Introduction}

Methionine (Met) is an essential sulfur amino acid. Some of the numerous biological functions of methionine include: methylation, growth promotion, detoxification and synthesis

\footnotetext{
* These authors equally participated in this manuscript. Correspondence to: Marija Stojanović, Institute of Medical Physiology „Richard Burian“, Faculty of Medicine, University of Belgrade, Višegradska 26, 11000 Belgrade, Serbia

E-mail: mrj.stojanovic@gmail.com
}

of cysteine and glutathione (GSH) (Yen et al. 2002; Kim et al. 2006; Tesseraud et al. 2009).

L-Met is the biologically active form of Met and represents a precursor for protein synthesis (Zhang et al. 2018).

Despite the importance of methionine to physiological functions, it is also recognized as a toxic amino acid (Benevenga and Steele 1984). It is possible that the toxicity of methionine proceeds from the disulfides formation. The complexity of its metabolism, which leads to the hyperhomocysteinemia, is another reason for its potential harmful role. Hyperhomocysteinemia has been detected in patients 
with inflammatory bowel disease (IBD). Digestive diseases (IBD) in which oxidative stress play a major role are linked to the mucosal free radicals formation. Since methionine is an amino acid widely present in the diet, we were wondering what effects it has on the digestive tract.

Today, there is a large body of evidence indicating that dietary methionine restriction is associated with, increased longevity and decreased incidence of age-related disorders in mice and rats (Zimmerman et al. 2003; Miller et al. 2005; Malloy et al. 2006). Literature data indicates protective effects of methionine restriction such as; inhibition of colon carcinogenesis, reduction in visceral fat, glucose and blood lipids concentrations (Komninou et al. 2006; Malloy et al. 2006). Additionally, delayed onset of numerous aging impairments such as "reduction in immune function“ is also a result of the methionine restriction diet (Miller et al. 2005). Literature data reported that the methionine restriction diet has potent anti-inflammatory effects in the mice model of colitis (Liu et al. 2017). Many potentially cellular mechanisms have been proposed, but there is little evidence to indicate a mechanism by which methionine restriction inhibits inflammation in the gut. One of the proposed mechanisms could be reduced production of reactive oxygen species (ROS) from numbers of inflammatory cells (eosinophils, neutrophils and macrophages) (Zhu and Li 2012). In truth, the amino acid methionine has a key role in the oxidative stress response, acting as a direct target of ROS, as its sulfur can be oxidized to sulfoxide (Campbell et al. 2016). Furthermore, methionine can act as a free radical scavenger and protect cells from oxidative stress (Luo and Levine 2009). Cysteine and glutathione (GSH) are products of the transsulfuration pathway in methionine metabolism, and can also be identified as ROS scavengers (Swennen et al. 2011).

On the other hand, methionine-rich diets have been associated with enhanced levels of free-radicals production and toxicity in rats and humans (Garlick 2006; Yalcinkaya et al. 2009; Gomez et al. 2011). Nevertheless, the latest research indicates that methionine diet supplementation in broilers have neutral impact on oxidative status (Zhang et al. 2018). The most commonly used supplemental sources of methionine in animals are DL-methionine (a mixture of the D-Met and L-Met) and DL-2-hydroxy-4-(methylthio) butanoic acid (DL-HMTBA).

DL-2-hydroxy-4-(methylthio) butanoic acid and D-Met must be converted to the physiologically active form of methionine which is L-met.

The dietary supplementation of methionine was found to improve intestinal integrity in weanling piglets (Chen et al. 2014). Additionally, the growth and development of the small intestine could be damaged by sulfur amino acid deficiency, as reported by the previous studies (Conde-Aguilera et al. 2016). Sulfur amino acid deficiency also decreased antioxidant capacity in piglets by reducing GSH and cysteine concentrations (Bauchart-Thevret et al. 2009).

L-cysteine was also found to attenuate oxidative stress in inflammatory bowel disease, via GSH synthesis $(\mathrm{Oz}$ et al. 2005). The small intestine serves as the principal site for the absorption of nutrients, water and electrolytes from the intestinal lumen. The intestinal mucosa expresses complex defence mechanisms and represent a key role in mucosal integrity (Verwelde and Jeurissen 1993; Hecht 2003; Ahmad et al. 2012). Methionine is absorbed from the diet with the highest fractional absorption rate among all proteinogenic amino acids, therefore, dietary methionine intake is considered very important for human and animal health benefits (Mastrototaro et al. 2016). Imbalance in redox regulation could damage the physiological functions of the intestine and contribute to the development of pathological processes. In addition, several studies with rats showed oxidative stress as a contributing factor for increased intestinal permeability (Sheth et al. 2003; Maeda et al. 2010). Moreover, it has been shown that the use of protective agents, such as L-cysteine, can alleviate oxidative stress and inflammation (Kim et al. 2009). Data analyzed N-acetylcysteine (NAC) administration, established that NAC protects tissue damage in ischemia-reperfusion injury (Cuzzocrea et al. 2000). This beneficial effect is explained due to its ability to scavenge free radicals. Furthermore, $\mathrm{N}$-acetylcysteine reduces the inflammatory process by inhibiting the production of proinflammatory cytokines (Tsuji et al. 1999). Therefore, potential clinical use of L-cysteine and $\mathrm{N}$-acetylcysteine should be considered.

However, to our knowledge, there is a lack of data about the effects of subchronic methionine administration in the rat intestine. Thus, the current study was conducted to investigate the effects of a three-week methionine application on the oxidative stress parameters and intestinal morphology in the rat ileum.

\section{Materials and Methods}

\section{Animals and design}

Wistar male albino rats (180-250 g) were used in our study. The age of rats at the beginning of the experiment was 15 to 20 days. They were acclimatized under standard laboratory conditions at $20 \pm 2^{\circ} \mathrm{C}, 50 \pm 15 \%$ relative humidity and normal photoperiod (12:12 light/dark cycle) for 7 days before the experiment. The rats were housed in transparent plexiglass cages and were provided with a commercial rat pellet diet and water ad libitum for 21 days.

After the acclimatization period, all the animals were randomly divided into 4 groups of 8 animals each, and 
treated for 21 days by intraperitoneal (i.p.) injections: Group K (control group): rats received only normal saline $(0.9 \% \mathrm{NaCl} ; 1 \mathrm{ml} /$ day $)$, Group M: rats were treated with methionine $(0.8 \mathrm{mmol} / \mathrm{kg} /$ day $)$; Group C: rats were treated with methionine $(0.8 \mathrm{mmol} / \mathrm{kg} /$ day $)+$ L-cysteine (7 mg/kg/day) (Liapi et al. 2009); Group N: rats were treated with methionine $(0.8 \mathrm{mmol} / \mathrm{kg} /$ day $)+\mathrm{N}$-acetylL-cysteine (50 mg/kg/day) (Akbulut et al. 2014). The doses of L-cysteine and N-acetyl-L-cysteine were selected based on earlier studies in which L-cysteine and N-acetylL-cysteine exhibited cytoprotective effects (Liapi et al. 2009; Akbulut et al. 2014).

After completion of the 21 day treatment, the animals were sacrificed by decapitation and the ileum tissue samples were taken for biochemical analysis and morphometric measurements.

All research procedures were performed in accordance with principles of good laboratory practice and the European Directive for Welfare of Laboratory Animals No: 2010/63/ EU. The ethics protocol of the current study was approved by the Ethics Committee of the Medical Faculty, University of Belgrade, Serbia (No: 3307/2). Experimental procedures were in accordance with the ethical standards of the Medical Faculty, University of Belgrade.

\section{Determination of oxidative stress parameters in the rat ileum by biochemical methods}

For the assessment of oxidative stress biomarkers, weighted segments of rat ileum were homogenized in phosphate buffer saline (PBS) (10\% weight/volume) using WiceTis HG-15D homogenizer. The homogenates were centrifuged at $10.000 \times g$ for 10 minutes, using refrigerated centrifuge (Microcentrifuge MiniSpin, Eppendorf AG, Germany). Superoxide dismutase (SOD) activity, glutathione peroxidase (GPx) activity, catalase (CAT) activity, reduced glutathione (GSH) content and the index of lipid peroxidation (MDA) were analyzed. All parameters were measured spectrophotometrically using UV/VIS spectrophotometer (UV-2601, Rayleigh, Mainland, China). The method of Bradford was used for protein concentration measurement (Bradford 1976).

\section{SOD activity}

The activity of total SOD was measured, as the change of extinction in time $(10 \mathrm{~min})$ at $480 \mathrm{~nm}$, kinetically. The SOD activity was determined as the percent of inhibition of epinephrine autooxidation under base conditions by tissue sampling. The reaction mixture contained epinephrine $(0.5 \mathrm{mmol} / \mathrm{l})$, Na-bicarbonate buffer ( $\mathrm{pH} 10.2)$ and $0.1 \mathrm{ml}$ of the sample; the reaction started by adding 0.1 $\mathrm{ml}$ of epinephrine solution $(0.01 \mathrm{M}$ into $0.01 \mathrm{M} \mathrm{HCl})$. The activity of SOD was presented as $\mathrm{U} / \mathrm{mg}$ of protein (Sun and Zigman 1987).

\section{GPx activity}

The activity of GPx in the rat ileum was determined using the method of Günzler (Günzler et al. 1974). Determination was based on oxidation of reduced GSH with GPx using NADPH. Glutathione reductase (GR) catalyzed the reaction. The decrease of absorbance at $340 \mathrm{~nm}$ was measured as a GPx activity, represented as $\mathrm{U} / \mathrm{mg}$ of protein.

\section{CAT activity}

CAT activity was determined according to the method of Aebi (1984), in which the disappearance of hydrogen peroxide is followed at $240 \mathrm{~nm}$. The reaction medium contained $30 \mathrm{mM} \mathrm{H} \mathrm{O}_{2}, 50 \mathrm{mmol} / \mathrm{l}$ potassium phosphate buffer $\mathrm{pH}$ 7.0, and $0.1 \mathrm{ml}$ sample. CAT activity was expressed as $\mathrm{U} / \mathrm{mg}$ protein.

\section{GSH content}

The Ellman's reagent was used for GSH content determination (Ellman 1959). It creates the yellow color anion, reacting with the aliphatic thiol compounds. The concentration of GSH was determined by reading the extinction on a spectrophotometer at $412 \mathrm{~nm}$. The content of GSH was expressed as $\mu \mathrm{mol} \mathrm{GSH} / \mathrm{mg}$ protein.

\section{Index of lipid peroxidation}

The index of lipid peroxidation was determined according to the method of Draper and Hadley (Draper and Hadley 1990), based on detection of malondialdehyde (MDA) concentration in ileum tissue samples homogenates. MDA, one of the final products of lipid peroxidation, reacts with thiobarbituric acid (TBA). At high temperatures, MDA participates with the TBA, to produce the red color conjugate, with the maximal absorption at $532 \mathrm{~nm}$. The intensity of induced lipid peroxidation was determined by adding ferric ions and ascorbic acid. The amount of generated MDA was measured at $533 \mathrm{~nm}$.

\section{Intestinal morphology analysis}

The ileal samples were fixed in $10 \%$ neutral buffered formalin and processed. Paraplast, and tissue sections (3-5 $\mu \mathrm{m}$ thick) were routinely stained with hematoxylin and eosin. Morphometric measurements were performed using an optical microscope Opton Photomicroscope III (Carl Zeiss AG, Oberkochen, Germany). The tissue elements of ileal mucosa, hand labeled on microphotographs were acquired with an 
Olympus C3030-Z digital camera (Olympus Deutschland $\mathrm{GmbH}$, Hamburg, Germany), projected on the monitor and then measured using a computer-aided image analysis software called Fiji (Schindelin et al. 2012). Measurements were performed on two sections for each tissue sample. All elements of the ileal mucosa were measured: villus height $(\mu \mathrm{m})$, tunica mucosa thickness $(\mu \mathrm{m})$, tunica muscularis thickness $(\mu \mathrm{m})$, as well as the total thickness of the ileal wall $(\mu \mathrm{m})$ using tissue samples with strictly longitudinal sections. The number of nucleated cells in the lamina propria (per $0.1 \mathrm{~mm}^{2}$ of tissue) was assessed on cross sections of the ileal mucosa.

All chemicals and reagents were obtained from Sigma (Sigma Chemical Co, St. Louis, MO, USA).

\section{Statistical analysis}

All results were expressed as means \pm standard error, representing eight rats in each group. The differences between means were assessed, and values of $p<0.05$ and $p<0.01$, $p<0.001$ were considered significant and highly significant, respectively. Groups of data were compared with an analysis of variance followed by the Bonferroni post-hoc test. A comparison was also performed using Student's $t$-test. Data were analyzed using Graph-Pad Prism 6 statistical software (GraphPad software; San Diego, CA).

\section{Results}

\section{Oxidative status parameters}

\section{SOD activity}

As presented in Figure 1A, three-week methionine treatment decreased the SOD activity by $73.04 \%$. Administration of both L-cysteine and N-acetyl-L-cysteine increased the SOD activity by $388.28 \%(p<0.01)$, and by $342.03 \%(p<0.05)$, respectively, compared to the Group $\mathrm{M}$.

\section{Glutathione peroxidase activity}

Activity of the GPx in the methionine-treated group decreased compared to the control values (by 17.74\%). A statistically significant increase appeared after L-cysteine treatment (by $234.68 \%, p<0.001$ ), as well as after $\mathrm{N}$-acetylL-cysteine application (by $123.58 \%, p<0.01$ ) (Fig. 1B).

\section{CAT activity}

CAT activity that was decreased following methionine application (by $16.78 \%, p>0.05$ ) was not statistically significant compared to the control. On the other hand, CAT activity
A

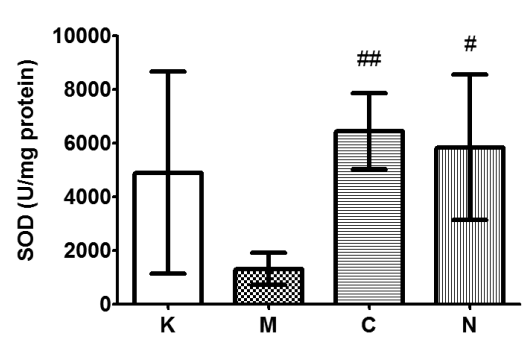

B

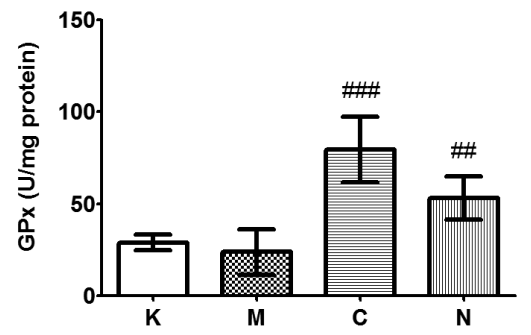

C

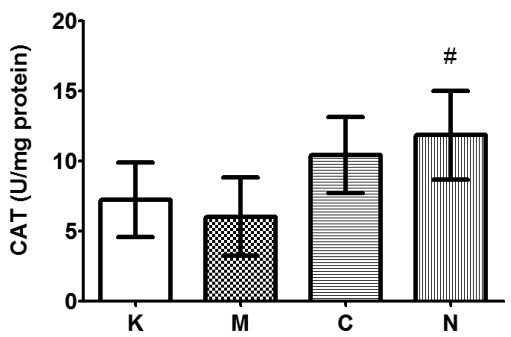

D

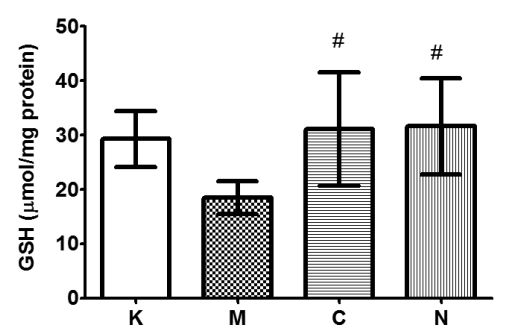

$E$

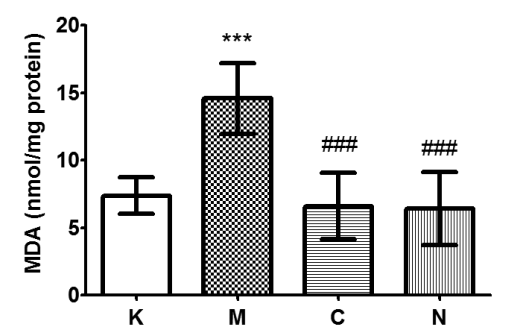

Figure 1. SOD activity (A), GPx activity (B), CAT activity (C), GSH content (D) and MDA concentration (E) in the ileum tissue homogenate after 21 day of treatment with sulfur amino acids. K, control group; $\mathrm{M}$, methionine group; $\mathrm{C}$, methionine + L-cysteine group; $\mathrm{D}$, methionine $+\mathrm{N}$-acetyl-L-cysteine group. \#\# $p<0.01 \mathrm{C} v s . \mathrm{M}$, \# $p<0.05 \mathrm{~N} v s . \mathrm{M}(\mathrm{A})$; \#\# $p<0.001 \mathrm{C} v s . \mathrm{M}$, \#\# $p<0.01 \mathrm{~N} v s . \mathrm{M}$ (B); $\# p<0.05 \mathrm{~N} v s . \mathrm{M}(\mathrm{C}) ; \# p<0.05 \mathrm{C} v s . \mathrm{M}, \mathrm{N} v s . \mathrm{M}(\mathrm{D}) ;{ }^{* * *} p<0.001 \mathrm{M} v s . \mathrm{K}, \# \# \#<0.001 \mathrm{C} v s . \mathrm{M}, \mathrm{N} v s . \mathrm{M}(\mathrm{E})$. 

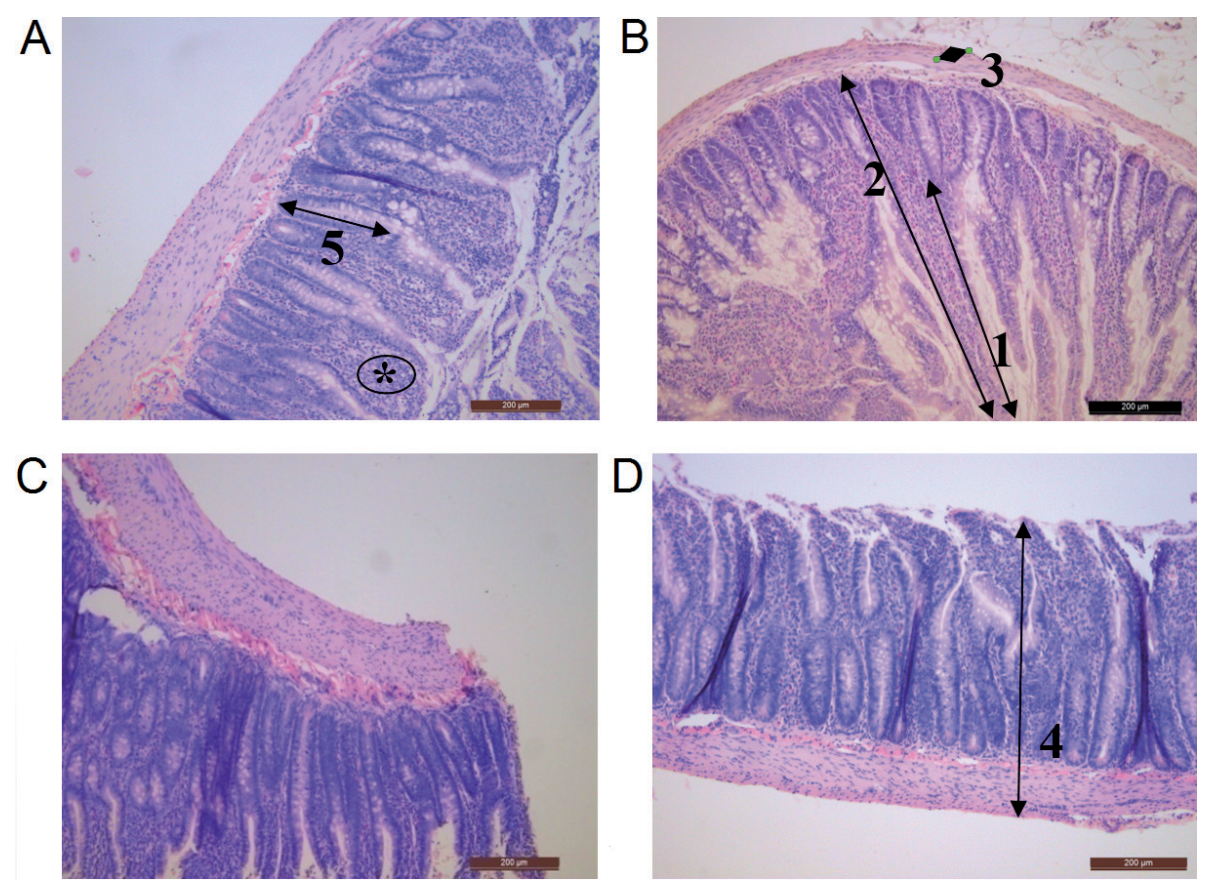

Figure 2. Ileum tissue samples in control conditions (A), during methionine loading (B) and after the administration of L-cysteine (C) or N-acetyl-L-cysteine (D) under methionine loading conditions. Staining with hematoxylin and eosin; original magnification: $200 \times$; 1 , length of ileal villi; 2 , tunica mucosa thickness; 3 , tunica muscularis thickness; 4, total wall thickness; 5 , crypt depth; asterisk, number of cells in lamina propria $/ 0.1 \mathrm{~mm}^{2}$.

was increased in Group C (by $72.60 \%, p>0.05$ ), and in Group N as well (by $96.62 \%, p<0.05$ ), compared to the Group M (Fig. 1C).

\section{Reduced glutathione content}

Reduced glutathione concentration was lower in the Group M compared to the control (by 36.83\%, $p>0.05$ ). However, when applied simultaneously with methionine, L-cysteine and N-acetyl-L-cysteine increased the GSH concentration by $68.29 \%$ and by $70.93 \%(p<0.05)$, respectively, in a statistically significant manner, in comparison to the Group M (Fig. 1D).

\section{Index of lipid peroxidation}

Index of lipid peroxidation, measured as MDA concentration, was increased in the Group M compared to the control values (by $97.62 \%, p<0.001$ ). Contrary to this, the concentration of MDA was decreased in the Group C (by $54.83 \%$, $p<0.001$ ) and in the Group N (by 56.09\%, $p<0.001$ ), compared to the Group M (Fig. 1E).

\section{Morphometry parameters in the rat ileum}

As presented in Figure 2, morphometry analysis was performed on the histological preparations of the rat ileum. Each parameter was tested in Group K, M, C and N. Analysis included determination of the following param- eters: length of the ileal villi, tunica mucosa thickness, tunica muscularis thickness, ileal wall thickness and number of cells per $0.1 \mathrm{~mm}^{2}$. The numerical values in parentheses were expressed as means \pm standard error for each parameter.

\section{Length of the ileal villi}

Methionine load was statistically highly significant and decreased the length of the ileal villi $(698.1 \pm 31.75 \mu \mathrm{m})$ compared to the control value $(863.8 \pm 34.17 \mu \mathrm{m})-$ decrease by $19.18 \%(p<0.01)$. In both of the Group C and N, the length of the ileal villi was decreased compared to the Group M $(p<0.001)$. The decrease following L-cysteine $(372.3 \pm 15.23 \mu \mathrm{m})$ application was by $46.67 \%$ and following N-acetyl-L-cysteine $(321.1 \pm 20.67 \mu \mathrm{m})$ by $54.00 \%$ (Fig. 3A; Table 1).

\section{Tunica mucosa thickness}

Tunica mucosa thickness was statistically significant $(p<0.01)$ decreased following methionine application $(742.6 \pm 28.88 \mu \mathrm{m})-$ decrease by $17.51 \%$ compared to the control $(900.2 \pm 38.19 \mu \mathrm{m})$. Both L-cysteine and $\mathrm{N}$ acetyl-L-cysteine statistically highly significant $(p<0.001)$ decreased mucosal thickness, compared to the Group M. The decrease in Group C (438.8 $\pm 7.10 \mu \mathrm{m})$ was by $40.91 \%$, and in Group N $(367.0 \pm 13.66 \mu \mathrm{m})$ was by $50.58 \%$ (Fig. 3B; Table 1). 
Table 1. Morphometric parameters of the rat ileum in control group, during methionine load and after application of L-cysteine and $\mathrm{N}$-acetyl-L-cysteine in methionine load conditions

\begin{tabular}{lcccc}
\hline & \multicolumn{4}{c}{ Group } \\
\cline { 2 - 5 } & $\mathrm{K}$ & $\mathrm{M}$ & $\mathrm{C}$ & $\mathrm{N}$ \\
\hline Length of the ileal villi $(\mu \mathrm{m})$ & $863.8 \pm 34.17$ & $698.1 \pm 31.75^{\mathrm{a}}$ & $372.3 \pm 15.23^{\mathrm{b}}$ & $321.1 \pm 20.67^{\mathrm{b}}$ \\
Tunica mucosa thickness $(\mu \mathrm{m})$ & $900.2 \pm 38.19$ & $742.6 \pm 28.88^{\mathrm{a}}$ & $438.8 \pm 7.10^{\mathrm{b}}$ & $367.0 \pm 13.66^{\mathrm{b}}$ \\
Tunica muscularis thickness $(\mu \mathrm{m})$ & $77.15 \pm 5.52$ & $92.91 \pm 10.19$ & $118.9 \pm 7.21$ & $100.9 \pm 6.79$ \\
Ileal wall thickness $(\mu \mathrm{m})$ & $994.4 \pm 44.89$ & $825.8 \pm 31.82^{\mathrm{a}}$ & $529.3 \pm 14.35^{\mathrm{b}}$ & $545.4 \pm 15.95^{\mathrm{b}}$ \\
Number of cells per $0.1 \mathrm{~mm}^{2}$ & $1347 \pm 36.89$ & $1511 \pm 39.97$ & $1432 \pm 103.6$ & $1428 \pm 91.30$ \\
Crypt depth $(\mu \mathrm{m})$ & $288.8 \pm 19.41$ & $159.3 \pm 24.5^{\mathrm{c}}$ & $83.3 \pm 14.70^{\mathrm{d}}$ & $81.23 \pm 13.47^{\mathrm{d}}$ \\
Villus height/crypt depth ratio & $3.1 \pm 0.14$ & $5.4 \pm 0.67^{\mathrm{e}}$ & $4.6 \pm 0.44$ & $4.1 \pm 0.45$ \\
\hline
\end{tabular}

The values are presented as the mean \pm standard error for 8 animals per group. ${ }^{a} p<0.01$ statistically highly significant difference in comparison to the Group $\mathrm{K},{ }^{\mathrm{b}} p<0.001$ statistically highly significant compared to the Group $\mathrm{M},{ }^{\mathrm{c}} p<0.001$ statistically highly significant difference iin comparison to the Group K. K, control group; M, methionine group; C, methionine + L-cysteine group; $\mathrm{D}$, methionine $+\mathrm{N}$-acetyl-L-cysteine group.

\section{Tunica muscularis thickness}

Methionine application increased tunica muscularis thickness $(92.91 \pm 10.19 \mu \mathrm{m})$ compared to the control group $(77.15 \pm 5.52 \mu \mathrm{m})-$ increase by $20.43 \%$. Tunica muscularis thickness was increased also in the Group C and N, compared to the Group M. There was an increase following L-cysteine application $(118.9 \pm 7.21 \mu \mathrm{m})$ by $27.97 \%$, and following N-acetyl-L-cysteine application $(100.9 \pm 6.79 \mu \mathrm{m})$ by $8.60 \%$. None of the changes were statistically significant (Fig. 3C; Table 1).

\section{Ileal wall thickness}

Methionine load induced a statistically highly significant $(p<$ $0.01)$ decrease of the ileal wall thickness $(825.8 \pm 31.82 \mu \mathrm{m})$ compared to the control value $(994.4 \pm 44.89 \mu \mathrm{m})$ - decrease by $16.95 \%$. Application of L-cysteine and N-acetyl-L-cysteine in the methionine load conditions produced a statistically highly significant decrease of the ileal wall thickness $(p<$ 0.001). Compared to the Group $M$, decrease following L-cysteine administration $(529.3 \pm 14.35 \mu \mathrm{m})$ was by $35.90 \%$, and following $\mathrm{N}$-acetyl-L-cysteine $(545.4 \pm 15.95 \mu \mathrm{m})$ was by $33.95 \%$ (Fig. 3D; Table 1).

\section{Number of cells per $0.1 \mathrm{~mm}^{2}$}

The number of cells in lamina propria tunicae mucosae increased by $12.17 \%$ in the Group M $(1511 \pm 39.97$ cells/ $\mathrm{mm}^{2}$ ) compared to the control $\left(1347 \pm 36.89\right.$ cells $\left./ \mathrm{mm}^{2}\right)$ and was not statistically significant. Both L-cysteine and $\mathrm{N}$-acetyl-L-cysteine induced a decrease in the number of cells compared to the Group M, which was not statistically significant. The decrease following L-cysteine administration $\left(1432 \pm 103.6\right.$ cells $\left./ \mathrm{mm}^{2}\right)$ was by $5.23 \%$, and following
$\mathrm{N}$-acetyl-L-cysteine $\left(1428 \pm 91.30\right.$ cells $\left./ \mathrm{mm}^{2}\right)$ was by $5.49 \%$ (Fig. 4A; Table 1).

\section{Crypt depth and the villus height/crypt depth (VH/CD) ratio}

Crypt depth was statistically highly significant $(p<0.001)$ decreased after methionine application $(159.3 \pm 24.5 \mu \mathrm{m})$ - decrease by $44.84 \%$ compared to the control (288.8 \pm $19.41 \mu \mathrm{m})$. Both L-cysteine and $\mathrm{N}$-acetyl-L-cysteine statistically significant $(p<0.05)$ decreased crypt depth compared to the Group M. The decrease in Group C $(83.3 \pm 14.7 \mu \mathrm{m})$ was by $47.71 \%$, and in Group N ( $81.23 \pm 13.47 \mu \mathrm{m})$ was by 49.01\% (Fig. 4B; Table 1).

Methionine load induced a statistically significant $(p<$ $0.05)$ increase of the $\mathrm{VH} / \mathrm{CD}$ ratio $(5.4 \pm 0.67)$ compared to the control $(3.1 \pm 0.14)$ - increase by $74.19 \%$. Villus height/ crypt depth ratio was decreased in the Group C and N, compared to the Group M. There was the decrease following L-cysteine application $(4.6 \pm 0.44)$ by $14.81 \%$, and following $\mathrm{N}$-acetyl-L-cysteine application $(4.1 \pm 0.45)$ by $24.07 \%$. None of the changes were statistically significant (Fig. 4C; Table 1).

\section{Discussion}

The literature data indicate that methionine induces the oxidative status changes in the intestine. Furthermore, it has been reported that methionine acts as a key protector of the intestinal mucosa, as an oxygen species scavenger (Luo and Levine 2009). Therefore, we examined the effects of subchronic methionine application on the oxidative stress parameters in the rat ileum tissue.

Oxidative stress is characterized by an imbalance between the antioxidative defence system and ROS production 
A

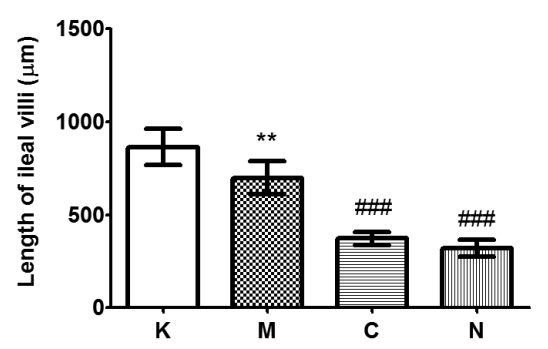

C

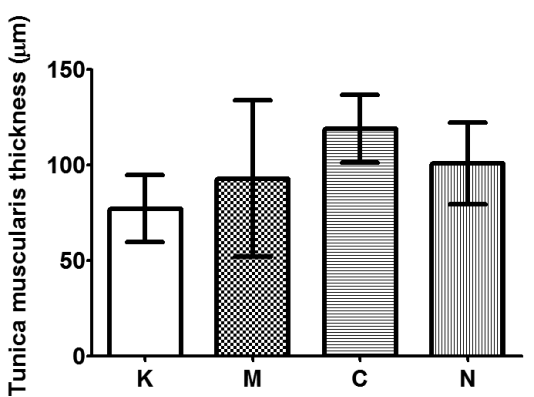

B

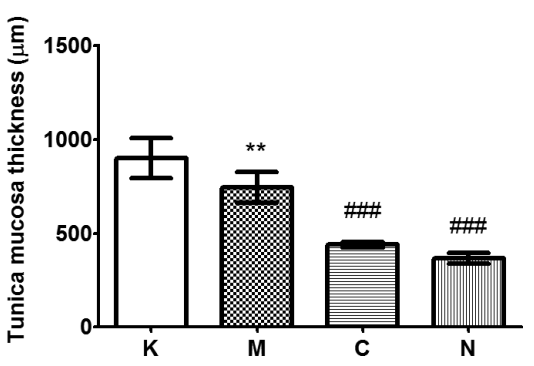

D

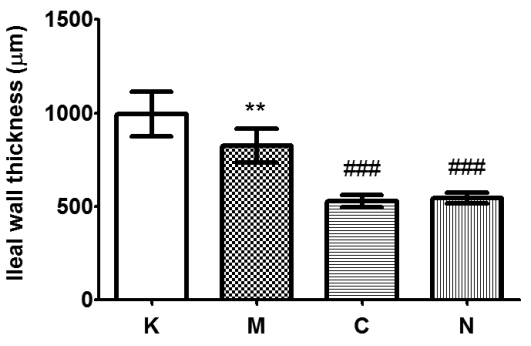

Figure 3. Length of ileal villi (A), tunica mucosa thickness (B), tunica muscularis thickness $(\mathbf{C})$, and ileal wall thickness (D) in control group (K), during methionine application $(\mathrm{M})$ and after the administration of L-cysteine $(\mathrm{C})$ or $\mathrm{N}$ acetyl-L-cysteine $(\mathrm{N})$ under methionine loading conditions. ${ }^{* *} p<0.01 \mathrm{M} v s . \mathrm{K}$; $\# \#$ \# $<0.001 \mathrm{C} v s . \mathrm{M}, \mathrm{N} v s . \mathrm{M}(\mathrm{A}, \mathrm{B}, \mathrm{D})$.
(Carden and Granger 2000). MDA, as the final product of lipid peroxidation, represents a good indicator of oxidative injury and intestine function impairment. Our results demonstrated increased levels of MDA concentration in the ileum tissue homogenate, after a three-week methionine treatment, compared to the control group. These results are consistent with our previous research, which included determination of the oxidative stress markers in the colon and liver tisssue homogenates, following methionine application (Stojanović et al. 2018a, 2018b). These effects could be explained by the prooxidative properties of the methionine. A contrary, recent study, has demonstrated that methionine diet supplementation for 28 days decreases the MDA level in the ileum of the piglets, which indicates its beneficial effects (Su et al. 2018).
Additionally, contrary to our results, study of Ruan et al. showed that methionine deficiency led to oxidative stress in the small intestine of broilers (Ruan et al. 2018). The explanation for the protective effect of methionine lies in the fact that methionine residues may have antioxidant properties, protecting the molecules where they are located. Further investigations would be needed to clarify the exact mechanism by which methionine affects intestine MDA concentration.

Nevertheless, harmful effects of lipid peroxidation in cells, could be, at least in part, alleviated by antioxidant activity of cysteine and glutathione (Swennen et al. 2011). Glutathione plays a key role in protecting the cells against free radicals. Although, there is a lack of information about the parenteral route of methionine application on oxida-
A

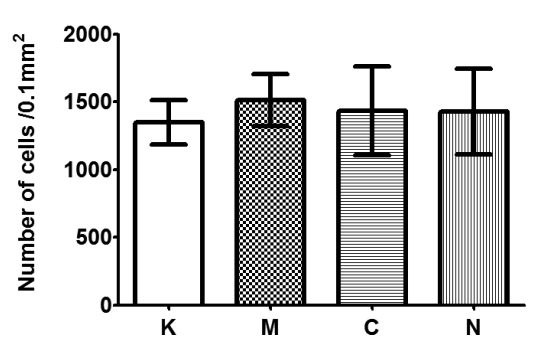

B

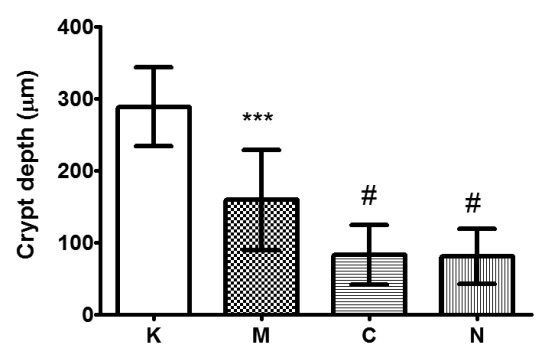

C

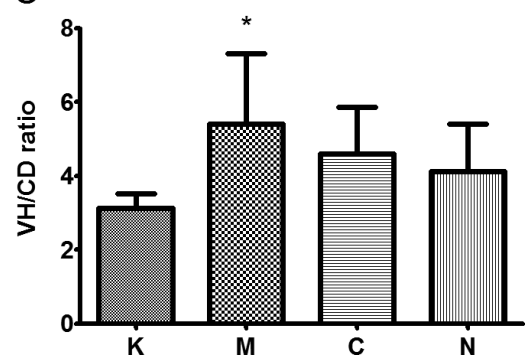

Figure 4. Number of cells per $0.1 \mathrm{~mm}^{2}$ (A), crypt depth (B) and villus height/crypt depth (VH/CD) ratio (C) in control group (K), during methionine application $(\mathrm{M})$ and after the administration of L-cysteine $(\mathrm{C})$ or N-acetyl-L-cysteine $(\mathrm{N})$ under methionine loading conditions. ${ }^{* *} p<0.001 \mathrm{M} v$ s. K; \# $p<0.05 \mathrm{C} v s . \mathrm{M}, \mathrm{N} v s . \mathrm{M}(\mathrm{B}) ;{ }^{*} p<0.05 \mathrm{M} v s . \mathrm{K}(\mathrm{C})$. 
tive status, literature data indicate that sulfur amino acid supplementation in diet influence the GSH content in the cell (Chen et al. 2013). Having that in mind, we observed the reduced glutathione concentration in the ileum tissue homogenates, after three-weeks of intaperitoneal methionine administration. Our results showed lower amounts of GSH in rats that received methionine i.p, compared to the control group. Therefore, in combination with our previous investigations (Stojanović et al. 2018a, 2018b), we demonstrated lowering of the reduced glutathione content in the liver and colon tissue homogenates after methionine treatment. We are free to conclude that methionine application compromised antioxidant status in these organs. Further, simultaneous application of methionine with L-cysteine (Group C) and N-acetyl-L-cysteine (Group N) was associated with increased GSH concentrations compared to the Group M. In accordance with our data, several studies have demonstrated that $\mathrm{N}$-acetylcysteine increases GSH levels in the liver, kidneys and lungs (Albelda et al. 1994; Sehirli et al. 2003; Sener et al. 2003). Overall, these findings indicate prooxidant properties of methionine and its potential harmful effects in the intestine, while L-cysteine and $\mathrm{N}$-acetylL-cysteine exhibit antioxidant effects. The cause of these effects of sulfur amino acids on GSH concentration are up until now still unknown. The suggested mechanism may involve alterations in enzymes included in the glutathione cycle - GSH reductase and GSH peroxidase.

Additionally, in our study, administration of L-cysteine and $\mathrm{N}$-acetyl-L-cysteine in the methionine loading conditions increased the activity of several key antioxidant enzymes: SOD, GPx and CAT, compared to the Group M. On the other hand, methionine reduced all the mentioned parameters in comparison with the control values, indicating its prooxidant properties. Likewise, $\mathrm{N}$-acetylcysteine protects small intestine functions in piglets that are challenged with lipopolysaccharide, by incresed SOD and CAT activity (Hou et al. 2012). These protective effects could be, in part, explained by antioxidant properties of L-cysteine and $\mathrm{N}$-acetyl-L-cysteine, achieved via regulating NF- $\kappa \mathrm{B}$ and Nrf signaling pathway (Song et al. 2016). Since the accumulating evidence has demonstrated that oxidative stress plays a critical role in inflammatory bowel disease, these results indicate that $\mathrm{L}$-cysteine and $\mathrm{N}$-acetyl-L-cysteine may have beneficial effects on the small intestine via oxidative stress reduction, as potential therapeutic agents (Alzoghaibi 2013).

In this study, methionine intervention decreased villus height, tunica mucosa thickness and total thickness of the ileal wall, compared to the control. Recent evidence to support our findings has indicated that there is lower crypt depth in the duodenum of weanling piglets, following methionine supplementation. (Chen et al. 2014). It is possible that methionine with its prooxidant properties leads to damage of the intestinal wall. Additionally, according to our results, the number of cells in lamina propria tunicae mucosae was increased following methionine application. This is consistent with our previous investigation which included colon tissue samples of the rat (Stojanović et al. 2018a). Similarly, recent studies have demonstrated that sulfur amino acid deficiency decreased the number of cells in the ileum of the piglets (Bauchart-Thevret et al. 2009). It is possible that methionine proinflammatory properties are responsible for the increasing of the lamina propria cellular infiltration.

In conclusion, the results of this study demonstrate harmful effects of methionine due to its prooxidant ability, as well as potential antioxidant properties of L-cysteine and $\mathrm{N}$-acetyl-L cysteine. Our findings provided the evidence that, gut function may be potentially improved by the modulation of the redox state by antioxidants. Further investigations are needed, to clarify the precise relationship between methionine metabolism and reactive oxygen species production. Finally, the results of this study may be helpful in the development of new therapeutic strategies for inflammatory bowel disease.

Acknowledgments. This work was supported by a Grant 175043 from the Ministry of Science and Technology of Serbia.

Conflict of interest. The authors declare that they have no conflict of interest.

\section{References}

Aebi H (1984): Catalase in vitro. Meth. Enzymol. 105, 121-126 https://doi.org/10.1016/S0076-6879(84)05016-3

Ahmad J, Ahamed M, Akhtar MJ, Alrokayan SA, Siddiqui MA, Musarrat J, Al-Khedhairy AA (2012): Apoptosis induction by silica nanoparticles mediated through reactive oxygen species in human liver cell line HepG2. Toxicol. Appl. Pharmacol. 259, 160-168

https://doi.org/10.1016/j.taap.2011.12.020

Akbulut S, Elbe H, Eris C, Dogan Z, Toprak G, Otan E, Erdemli E, Turkoz Y (2014): Cytoprotective effects of amifostine, ascorbic acid and $\mathrm{N}$-acetylcysteine against methotrexate- induced hepatotoxicity in rats. World J. Gastroenterol. 20, 10158-10165 https://doi.org/10.3748/wjg.v20.i29.10158

Albelda SM, Smith CW, Ward PA (1994): Adhesion molecules and inflammatory injury. FASEB J. 8, 504-512 https://doi.org/10.1096/fasebj.8.8.8181668

Alzoghaibi MA (2013): Concepts of oxidative stress and antioxidant defense in Crohn's disease. World J. Gastroenterol. 19, 6540-6547 https://doi.org/10.3748/wjg.v19.i39.6540

Bauchart-Thevret C, Stoll B, Chacko S, Burrin DG (2009): Sulfur amino acid deficiency upregulates intestinal methionine cycle activity and suppresses epithelial growth in neonatal pigs. Am. J. Physiol. Endocrinol. Metab. 296, 1239-1250 https://doi.org/10.1152/ajpendo.91021.2008 
Benevenga NJ, Steele RD (1984): Adverse-effects of excessive consumption of amino-acids. Annu. Rev. Nutr. 4, 157-181 https://doi.org/10.1146/annurev.nu.04.070184.001105

Bradford MM (1976): A rapid and sensitive method for the quantitation of microgram quantities of protein utilizing the principle of protein-dye binding. Anal. Biochem. 72, 248-254 https://doi.org/10.1016/0003-2697(76)90527-3

Campbell K, Vowinckel J, Keller MA, Ralser M (2016): Methionine metabolism alters oxidative stress resistance via the pentose phosphate pathway. Antioxid. Redox Signal. 24, 543-547 https://doi.org/10.1089/ars.2015.6516

Carden DL, Granger DN (2000): Pathophysiology of ischemiareperfusion injury. J. Pathol. 190, 255-266 https://doi.org/10.1002/(SICI)1096-9896(200002)190:3<255::AID-PATH526 $>3.0 . \mathrm{CO} ; 2-6$

Chen Y, Li D, Dai Z, Piao X, Wu Z, Wang B, Zhu Y, Zeng Z (2014): 1-Methionine supplementation maintains the integrity and barrier function of the small-intestinal mucosa in postweaning piglets. Amino Acids 46, 1131-1142 https://doi.org/10.1007/s00726-014-1675-5

Chen YP, Chen X, Zhang H, Zhou YM (2013): Effects of dietary concentrations of methionine on growth performance and oxidative status of broiler chickens with different hatching weight. Brit. Poultry Sci. 54, 531-537 https://doi.org/10.1080/00071668.2013.809402

Conde-Aguilera JA, Le Floc'h N, Le Huërou-Luron I, Mercier Y, Tesseraud S, Lefaucheur L, van Milgen J (2016): Splanchnic tissues respond differently when piglets are offered a diet $30 \%$ deficient in total sulfur amino acid for 10 days. Eur. J. Nutr. 55, 2209-2219 https://doi.org/10.1007/s00394-015-1031-x

Cuzzocrea S, Mazzon E, Costantino G, Serraino I, De Sarro A, Caputi AP (2000): Effects of $\mathrm{N}$-acetylcysteine in a rat model of ischemia reperfusion injury. Cardiovasc. Res. 47, 537-548 https://doi.org/10.1016/S0008-6363(00)00018-3

Draper H, Hadley M (1990): Malondialdehyde determination as index of lipid peroxidation. Meth. Enzymol. 186, 421-431 https://doi.org/10.1016/0076-6879(90)86135-I

Ellman GL (1959): Tissue sulfhydryl groups. Arch. Biochem. Biophys. 82, 70-77 https://doi.org/10.1016/0003-9861(59)90090-6

Garlick PJ (2006): Toxicity of methionine in humans. J. Nutr. 136, $1722-1725$ https://doi.org/10.1093/jn/136.6.1722S

Gomez J, Sanchez-Roman I, Gomez A, Sanchez C, Suarez H, Lopez-Torres M, Barja G (2011): Methionine and homocysteine modulate the rate of ROS generation of isolated mitochondria in vitro. J. Bioenerg. Biomembr. 43, 377-386 https://doi.org/10.1007/s10863-011-9368-1

Günzler WA, Kremers H, Flohe L (1974): An improved coupled test procedure for glutathione peroxidase (EC 1-11-1-9-) in blood. Z. Klin. Chem. Klin. Biochem. 12, 444-448 https://doi.org/10.1515/cclm.1974.12.10.444

Hecht GA (2003): Microbial Pathogenesis and the Intestinal Epithelial Cell. pp. 60-66, ASM Press, Washington https://doi.org/10.1128/9781555817848

Hou Y, Wang L, Zhang W, Yang Z, Ding B, Zhu H, Liu Y, Qiu Y, Yin Y, Wu G (2012): Protective effects of $\mathrm{N}$-acetylcysteine on intestinal functions of piglets challenged with lipopolysaccharide. Amino Acids 43, 1233-1242 https://doi.org/10.1007/s00726-011-1191-9

Kim CJ, Kovacs-Nolan J, Yang C (2009): L-cysteine supplementation attenuates local inflammation and restores gut homeostasis in a porcine model of colitis. Biochim. Biophys. Acta 1790, 1161-1169 https://doi.org/10.1016/j.bbagen.2009.05.018

Kim WK, Froelich CA, Patterson PH, Ricke SC (2006): The potential to reduce poultry nitrogen emissions with dietary methionine or methionine analogues supplementation. World Poultry Sci. J. 62, 338-353 https://doi.org/10.1079/WPS2005103

Komninou D, Leutzinger Y, Reddy BS, Richie JP (2006): Methionine restriction inhibits colon carcinogenesis. Nutr. Cancer 54, 202-208 https://doi.org/10.1207/s15327914nc5402_6

Liapi C, Zarros A, Theocharis S, Al-Humadi H, Anifantaki F, Gkrouzman E, Mellios Z, Skandali N, Tsakiris S (2009): The neuroprotective role of L-cysteine towards the effects of shortterm exposure to lanthanum on the adult rat brain antioxidant status and the activities of acetylcholinesterase, $(\mathrm{Na}+\mathrm{K}+)$-and Mg2+-ATPase. Biometals 22, 329-335 https://doi.org/10.1007/s10534-008-9169-0

Liu G, Yu L, Fang J, Hu C.A, Yin J, Ni H, Ren W, Duraipandiyan V, Chen S, Al-Dhabi NA, Yin Y (2017): Methionine restriction on oxidative stress and immune response in dss-induced colitis mice. Oncotarget 8, 44511-44520

https://doi.org/10.18632/oncotarget.17812

Luo S, Levine R.L. (2009): Methionine in proteins defends against oxidative stress. FASEB J. 23(2), 464-472

https://doi.org/10.1096/fj.08-118414

Maeda T, Miyazono Y, Ito K, Hamada K, Sekine S, Horie T (2010): Oxidative stress and enhanced paracellular permeability in the small intestine of methotrexate-treated rats. Cancer Chemother. Pharmacol. 65, 1117-1123 https://doi.org/10.1007/s00280-009-1119-1

Malloy VL, Krajcik RA, Bailey SJ, Hristopoulos G, Plummer JD, Orentreich N (2006): Methionine restriction decreases visceral fat mass and preserves insulin action in aging male Fischer 344 rats independent of energy restriction. Aging Cell 5, 305-314 https://doi.org/10.1111/j.1474-9726.2006.00220.x

Mastrototaro L, Sponder G, Saremi B, Aschenbach JR (2016): Gastrointestinal methionine shuttle: priority handling of precious goods. IUBMB Life 68, 924-934 https://doi.org/10.1002/iub.1571

Miller RA, Buehner G, Chang Y, Harper JM, Sigler R, SmithWheelock M (2005): Methionine-deficient diet extends mouse lifespan, slows immune and lens aging, alters glucose, T4, IGF-I and insulin levels, and increases hepatocyte MIF levels and stress resistance. Aging Cell 4, 119-125 https://doi.org/10.1111/j.1474-9726.2005.00152.x

Oz HS, Chen TS, McClain CJ (2005): Antioxidants as novel therapy in a murine model of colitis. J. Nutr. Biochem. 16, 297-304 https://doi.org/10.1016/j.jnutbio.2004.09.007

Ruan T, Li L, Lyu Y, Luo Q, Wu B (2018): Effect of methionine deficiency on oxidative stress and apoptosis in the small intestine of broilers. Acta Vet. Hung. 66, 52-65 
https://doi.org/10.1556/004.2018.006

Schindelin J, Arganda-Carreras I, Frise E, Kaynig V, Longair M, Pietzsch T, Preibisch S, Rueden C, Saalfeld S, Schmid B, et al. (2012): Fiji: an open-source platform for biological-image analysis. Nat. Methods 9, 676-682 https://doi.org/10.1038/nmeth.2019

Sehirli AÖ, Sener G, Satıroğlu H, Ayanoğlu-Dülger G (2003): Protective effect of $\mathrm{N}$-acetylcysteine on renal ischemia/reperfusion injury in rat. J. Nephrol. 16, 75-80

Sener G, Tosun O, Sehirli AÖ, Kacmaz A, Arbak S, Ersoy Y, Ayanoğlu-Dülger G (2003): Melatonin and N-acetylcysteine have beneficial effects during hepatic ischemia and reperfusion. Life Sci. 72, 2707-2718 https://doi.org/10.1016/S0024-3205(03)00187-5

Sheth P, Basuroy S, Li C, Naren AP, Rao RK (2003): Role of phosphatidylinositol 3-kinase in oxidative stress-induced disruption of tight junctions. J. Biol. Chem. 278, 49239-49245 https://doi.org/10.1074/jbc.M305654200

Song Zh, Tong G, Xiao K, Jiao le F, Ke Yl, Hu Ch (2016): L-cysteine protects intestinal integrity, attenuates intestinal inflammation and oxidant stress, and modulates NF- $\mathrm{KB}$ and Nrf2 pathways in weaned piglets after LPS challenge. Innate Immun. 22, 152-161 https://doi.org/10.1177/1753425916632303

Stojanović M, Šćepanović L, Todorović D, Mitrović D, Šćepanović V, Šćepanović R, Ilić S, Šćepanović T, Borović M.L, Milićević Ž, et al. (2018a): Suppression of methionine-induced colon injury of young rats by cysteine and $\mathrm{N}$-acetyl-L-cysteine. Mol. Cell. Biochem. 440, 53-64 https://doi.org/10.1007/s11010-017-3155-1

Stojanović M, Todorović D, Šćepanović L, Mitrović D, Borozan S, Dragutinović V, Labudović-Borović M, Krstić D, Čolović M, Djuric D (2018b): Subchronic methionine load induces oxidative stress and provokes biochemical and histological changes in the rat liver tissue. Mol. Cell. Biochem. 448, 43-50 https://doi.org/10.1007/s11010-018-3311-2

Su W, Zhang H, Ying Z, Li Y, Zhou L, Wang F, Zhang L, Wang T (2018): Effects of dietary L-methionine supplementation on intestinal integrity and oxidative status in intrauterine growthretarded weanling piglets. Eur. J. Nutr. 57, 2735-2745 https://doi.org/10.1007/s00394-017-1539-3

Sun M, Zigman S (1987): An improved spectrophotometric assay for superoxide dismutase based on epinephrine autooxidation. Anal. Biochem. 90, 81-89 https://doi.org/10.1016/0003-2697(78)90010-6

Swennen Q, Geraert PA, Mercier Y, Everaert N, Stinckens A, Willemsen H, Buyse J (2011): Effects of dietary protein content and 2-hydroxy-4-methylthiobutanoic acid or DL-methionine supplementation on performance and oxidative status of broiler chickens. Br. J. Nutr. 106, 1845-1854 https://doi.org/10.1017/S0007114511002558

Tesseraud S, Métayer Coustard S, Collin A, Seiliez I (2009): Role of sulfur amino acids in controlling nutrient metabolism and cell functions: implications for nutrition. Br. J. Nutr. 101, 1132-1139 https://doi.org/10.1017/S0007114508159025

Tsuji F, Miyake Y, Aono H, Kawashima Y, Mita S (1999): Effects of bucillamine and $\mathrm{N}$-acetylcysteine on cytokine production and collogen-induced arthritis. Clin. Exp. Immunol. 115, 26-31 https://doi.org/10.1046/j.1365-2249.1999.00749.x

Verwelde L, Jeurissen SHM (1993): Postnatal development of intraepithelial leukocytes in the chicken digestive tract: phenotypical characterisation in situ. Cell Tissue Res. 274, 295-301 https://doi.org/10.1007/BF00318748

Yalcinkaya S, Unlucerci Y, Giris M, Olgac V, Dogru-Abbasoglu S, Uysal M (2009): Oxidative and nitrosative stress and apoptosis in the liver of rats fed on high methionine diet: protective effect of taurine. Nutrition 25, 436-444 https://doi.org/10.1016/j.nut.2008.09.017

Yen CL, Mar MH, Craciunescu CN, Edwards LJ, Zeisel SH (2002): Deficiency in methionine tryptophan isoleucine or choline induces apoptosis in cultured cells. J. Nutr. 132, 1840-1847 https://doi.org/10.1093/jn/132.7.1840

Zhang S, Gilbert ER, Saremi B, Wong EA (2018): Supplemental methionine sources have a neutral impact on oxidative status in broiler chickens. J. Anim. Physiol. Anim. Nutr. (Berl.) 102, 1274-1283 https://doi.org/10.1111/jpn.12946

Zhu H, Li YR (2012): Oxidative stress and redox signaling mechanisms of inflammatory bowel disease: updated experimental and clinical evidence. Exp. Biol. Med. (Maywood) 237, 474-480 https://doi.org/10.1258/ebm.2011.011358

Zimmerman JA, Malloy V, Krajcik R, Orentreich N (2003): Nutritional control of aging. Exp. Gerontol. 38, 47-52 https://doi.org/10.1016/S0531-5565(02)00149-3

Received: December 29, 2018

Final version accepted: August 7, 2019 